\title{
TREN SAAT INI DAN MASALAH DALAM AKSES OPEN AKSES DAN KOMUNIKASI ILMIAH
}

\section{Nurmarliana Harum Harahap dan Cindy Fadilah Nasution Fakultas Ilmu Sosial \\ Ilmu Perpustakaan Universitas Islam Negeri Sumatera Utara E-mail : harum.hrp@gmail.com}

\begin{abstract}
Abstrak
Seiring dengan perkembangan internet yang semakin canggih perilaku pencarian informasi pun ikut beralih dengan memanfaatkan teknologi yang ada seperti memanfaatkan search engine yang ada, tentunya hal ini dapat memberikan kita informasi yang cepat,tepat dan tanggap yang dalam hasilnya juga bisa berupa ebooks maupun ejournals. Open Akses (OA) dapat kita simpulkan sebagai strategi atau cara untuk kita dapat mengakses atau mendapatkan karya ilmiah yang bersifat digital, baik itu memiliki hak kebebasan hak cipta maupun tidak, tanpa adanya batas lisensi serta bebas biaya yang tentunya demi keperluanyang berkaitan dengan keilmuan. Sebagaimana yang sudah disetujui dunia akademik, secara mendunia atau global bahwa kebebasan akses informasi saat ini sangat dilegalkan terlebih lagi jika tujuannya itu bersifat ilmiah bukan komersial. Dalam hal ini komunikasi ilmiah mengambil peran sebagai suatu kegiatan dimana hasil-hasil karya ilmiah dari para peneliti yang sudah diciptakan di eavluasi kualitasnya sehingga dapat di sebarluaskan kepada masyarakat ilmiah tentunya dengan tujuan agar penelitian atau hasil karya ilmiah ini tetap bisa digunakan di masa depan.
\end{abstract}

Kata Kunci: Open Akses, Komunikasi Ilmiah.

\begin{abstract}
Along with the development of increasingly sophisticated internet information search behavior has also been switched by utilizing existing technologies such as utilizing existing search engines, of course this can provide us with fast, accurate and responsive information which in the results can also be in the form of ebooks or ejournals. We can conclude Open Access (OA) as a strategy or way for us to be able to access or obtain scientific works that are digital, whether they have copyright rights or not, without any licensing limits and free of charge which is certainly for the sake of scientific related needs. As has been agreed by the academic world, globally or globally that the freedom of access to information is now highly legal especially if the goal is scientific rather than commercial. In this case, scientific communication takes on the role
\end{abstract}


of an activity where the results of scientific work from researchers that have been created in eavluation are of high quality so that they can be disseminated to the scientific community, of course, with the aim that research or scientific work can still be used in the future.

Keywords: Open Access, Scientific Communication. 


\section{A. Latar Belakang Masalah}

Sebelum Zaman internet (Pra-internet), jika seseorang hendak menemukan sebuah informasi atau bahan rujukan yang dibutuhkannya haruslah mengunjungi perpustakaan dan melakukan akses manual baik itu berupa buku text maupun jurnal yang masih tercetak tentunya. Seiring berjalnnya waktu muncullah internet yang lambat laun berkembang dengan pesatnya dari zaman ke zaman, seiring dengan perkembangan internet tersebut perilaku pencarian informasi pun ikut beralih dengan memanfaatkan teknologi yang ada seperti memanfaatkan search engine yang tentunya hal ini dapat memberikan kita informasi yang cepat,tepat dan tanggap yangjuga bisa melalui ebooks maupun ejournals.yah yang tentunya sudah ada tambahan huruf E- di awalnya yang menandakan buku atau jurnal tersebut sudah berubah bentuk atau beralih dari yang awalnya manual menjadi elektronik.

Bagaimanapun dalam menyebarluaskan Ilmu pengetahuan tentunya kita memerlukan sebuah perantara berupa media KOMIL yang tepat sebagai kunci utama. Media KOMIL yang booming dan trend dimasa kini bisa dilakukan dengan komunikasi ilmiah secara tertulis, salah satunya melalui 'Open Access (OA)'. Saat ini permasalahan yang sering muncul di beberapa perpustakaan yakni terpaksa menghentikan langganan jurnal dan majalah. Penyebabnya bermacam-macam, misalnya: adanya kenaikan harga jurnal sehingga biaya langganannya menjadi mahal, sementara anggaran perpustakaannya tidak mencukupi. Ditambah lagi masalah yang terkait dengan instansi atau lembaga-lembaga negeri yang terikat dengan kebijakan pengadaan jurnal yang prosesnya cukup rumit hal ini disebabkan karena harus mengikuti prosedur atau langkah-langkah 
pengadaan barang dan jasa yang memiliki syarat dan ketentuan tertentu.

\section{B. Tren Saat Ini Dan Masalah Dalam Akses Open Akses}

\section{Pengertian Open Akses}

Open akses atau umumnya yang disingkat dengan OA, mengacu pada hasil penelitian daring yang bebas dari semua pembatasan akses (misalnya biaya akses) dan bebas daribanyak pembatasan penggunaan (misalnya pembatasan hak cipta dan lisensi tertentu).Lanjutnya Open Akses atau akses terbuka adalah dimana kita dapat mengakses informasi secara gratis dan bebas secara penuh kapan saja dan dimanapun, yang tentu saja hal ini didukung oleh adanya keberadaan teknologi digital dan akses ke sumber informasi dalam bentuk digital yang di sediakan untuk mereka yang membutuhkan informasi ilmiah yang sudah berbentuk digital kapan saja dan dimanapun ia berada .

Open Akses (OA) dapat kita tarik kesimpulannya sebagai strategi atau cara untuk kita dapat mengakses atau mendapatkan karya ilmiah yang bersifat digital baik itu mempunyai atau memiliki hak kebebasan hak cipta maupun tidak, tanpa adanya batas lisensi serta bebas biaya yang tentunya demi keperluanyang berkaitan dengan keilmuan. Sebagaimana yang sudah disetujui dunia akademik, secara mendunia atau global bahwa kebebasan akses informasi saat ini sangat dilegalkan terlebih lagi jika tujuannya itu bersifat ilmiah bukan komersial. Selain itu, seperti yang sudah kita lihat sekarang ini banyak sekali penelitian yang sudah dibiayai oleh pemeritah kita terutama segala hal yang berkaitan dengan penelitian yang bersifat ilmiah 


\section{Trend Perkembangan Open Acces}

Open Access (OA) atau yang biasa kita sebut sebagai akses terbuka saat ini dapat kita katakan sebagai salah satu cara yang paling alternatif dalam menyebar luaskan informas- informasi ilmiah yang ada kepada seluruh penjuru dunia tanpa dibatasi oleh yang namanya ruang,tempat dan waktu. Open Akses dalam hal ini adalah dimana kita dapat membuka akses informasi yang online maupun yang bersifat digital tanpa dikenakan biaya dan tanpa izin dari si pembuat karya ilmiah tersebut yang kita butuhkan tentunya. Baik itu karya ilmiah dari mahasiswa lain,staf perguruan tinggi, sebuah instansi, penulis ternama bahkan seorang dosen sekalipun .

disebarluskan atau pundi publikasikan melalui internet secara terbuka tanpa adanya persyaratan-persyaratan tetentu. ${ }^{38}$

Hal ini sampai sekarang tentu saja masih diperjuangkan oleh sebuah lembaga yang bernama (OAI) atau Open Archives Initiative yaitu lembaga yang sampai sekarang ini yang terus berinisiatif dalam hal memperjuangkan Open Akses bagi karyakarya ilmiah yang ada agar tidak Close Acces .inisiatif OAI ini sendiri pertama kali dilaksanakan di Budapest tepatnya pada Tahun 2001 yang mempunyai tujuan agar adanya perubahan besar-besaran terkait dengan sistem komunikasi ilmia agar lebih baik kedepannya.

Bahkan OAI juga sempat melakukan reformasi Sistem komunikasi ilmiah yang memang sebenarnya juga sudah sempat dilakukan sebelum-sebelumnya. Dan tentu saja bukan hal yang sia-sia Inisiatif yang dilakukan ini akhirnya telah mendorong dan membuatsegenap civitas akademika serta para ilmuwan,peneliti,dosenserta sarjanawan untuk mempublikasikan

\footnotetext{
${ }^{38}$ Chusnul Chatimah Asmad, Taufiq Mathar, and A Khaidir Akbar, 'TREN PERKEMBANGAN OPEN
} ACCESS INSTITUTIONAL REPOSITORY PADA', 2018. 
artikel ilmiah mereka sendiri pada jurnal yang berbasis Open Akses danjuga tentunya repositori berbasis Open Akses. Yang akhirnya dengan hal ini OAI telah mewujudkan dan mem,bangkitkan Harapan masyarakat yang berkecimpung di dunia akademik di seluruh dunia sehingga bisa mendapatkan serta mengakses informasi ilmiah yang dibutuhkannya tanpa terhalang oleh beberpa persyaratan tertentu terutama terkait dengan hal materi .

Di zaman sekarang ini Open Akses lagi hangat dan trending di perbincangkan oleh masyarakat luas, karena kehadirannya dinilai sangat memberi peran dan kontribusi yang cukup besar dalam membantu para peneliti dari berbagai belahan dunia khususnya di negara-negara berkembang guna untuk mengakses rujukan-rujukan literatur yang bersifat ilmiah tanpa adanya hambatan atau persyaratan-persyaratan yang dibutuhkan.

Walaupun demikian, tanpa adanya kebijakan Open Akses di sebuah perguran tinggi, ada beberapa direktori dan database yang secara Cuma-Cuma memberikan free access seperti Directory Open Access Journal (DOAJ), The Health Inter Network Access to Research Initiative (HINARI), Online Access to Research in the Invironment (OARE), Journal Storage, Jstor,dan lain sebagainya. Hanya saja penyedia literatur atauppun karya-karya ilmiah yang telah disebutkan ini ada yang tidak dapat diakses secara individu, yang membuat perguruan tinggi mau tidak mau harus melanggannya agar lietratur dan karya-karya ilmiah yang terdapat di direktori atau database tersebut dapat di akses oleh para semua kalangan kampus dan khususnya para peneliti secara bebas . Saat ini OA sangat dibutuhkan dalam menumbuhkan dan mengembangkan aktivitas penelitian di negara berkembang khususnya di Indonesia. Banyak perguruan tinggi yang telah 
menerapkan hal tersebut, namun ada beberapa diantaranya salah mengertitentang hakikat dari Open Akses yang sebetulnya. ${ }^{39}$ Adanya gerakan Open Akses tentunya telah menjadi salah satu model KOMIL yang lebih mengutamakan peningkatan akses dari hasil penelitian. Open Akses dalam hal ini akan membuat situasi dan kondisi untuk sistem informasi yang sudah bersifat global yang lebih efektif melalui budaya akses terbuka dan berbagi.

\section{Ciri Khas dari Open Akses}

Adapun ciri khas dari Open Akses, antara lain:

1. Tersedia dalam format literatur digital, yang bisa di akses secara cepat dan langsung serta akses online permanen.

2. Setelah melakukan akses online kita dapat memperoleh teks lengkap dari artikel hasil penelitian.

3. Free of charge, Maksudnya adalah penulis tidak dibayar.

4. pay per view atau membayar biaya ongkos per satu kali akses maksudnya kitamembayar biaya ongkos hanya pada saat pengaksesan pertama, hal ini tentu saja bagi mereka yang belum melakukan pelangganan, serta bebas dari hambatan salah satu bentuk hambatannya yaitu harga langganan.

5. Bebas mengakses tanpa adanya hambatan biaya apapun (free access without anything fee),

6. Free dari semua hambatan dan ikatan yang menyangkut hak cipta (free of most copyright),

7. Serta tidak memerlukan batas perijinan (licensing restrictions). 40

\footnotetext{
${ }^{39}$ Asmad, Mathar, and Akbar.

${ }^{40}$ Endang Fatmawati, 'Revolusi Budaya Digitalisasi Informasi: Dampaknya Bagi Pustakawan Dalam Mengelola Pengetahuan', 11.02 (2017), 1-16.
} 
Agar gerakan Open Akses tetap berjalan dengan baik perlu adanyadukungan dari semua kalangan khususnya yang berkecimpung di dunia akademik serta membutuhkan pola pikir yang integral. Sejatinya Open Akses sudah dari dulu, hanya saja pada saat itu istilah dari Open Akses belum sebuming sekarang dan belum dipraktekkan pengaplikasiannya secara menyeluruh. Namun, ternyata beberapa waktu terakhir ini sudah mulai tampak gerakan open akses mulai trend dan popular lagi di negara kita tercinta Indonesia. Bahkan kabar baiknya lagi beberapa perguruan tinggi di indonesia sudah melaksanakan road show seminar nasional yang berkaitan dengan trendinya Open Akses sekarang ini adapun tema dari seminar ini adalah 'Access : The Future of Repositories and Scholarly Publishing'. Adapun Perguruan tinggi yang sudah mengadakan seminar tersebut yaitu UK Petra Surabaya (28/ 01/ 2013), Perpustakaan USU Medan (30 /01/ 2013), dan Perpustakaan UI Jakarta (1 /02 2013).41

\section{Masalah Yang sering Muncul Dalam Open Akses}

1. Plagiasi, Di era Open Akses sekarang ini dengan keterbukaan akses yang sudah ada sangat rawan bahkan sering terjadi terjadi tindakan plagiasi, hal ini tentu saja didukung oleh fasilitas-fasilitas yang sudah tersedia di internet yang memberikan kemudahan kepada semua orang tyanpa terkecuali untuk mengunduh dan menyalin karya orang lain tanpa mencantumkan sumber aslinya. Yang lebih mirisnya mengakui karya tersebut sebagai hasil karya nya sendiri.

2. Perbedaan persepsi pimpinan, Pimpinan yang memeiliki wawasan yang luas dan sudah paham betul dengan teknologi pada umumnya akan mendukung penuh gerakan open akses,

\footnotetext{
${ }^{41}$ Fatmawati.
} 
sedangkan pimpinan yang pengetahuan akan teknologinya terbatas akan menolak geraka open akses dengan alasan khawatir akan terjadinya plagiarisme serta penyalahgunaan karya akademik.

3. Pro dan Kontra terkait Web rank, Jika Akses terbuka di terapkan didalam sebuah institusi maka institusi tersebut akan ikut di peringkat-kan di Web Rank yang tentunya akan meningkatkan visibilitas institusi.

4. Standar Kualitas Karya Ilmiah, Beberpa hasil karya ilmiah dosen dan mahasiswa belum memenuhi standar kualitas sebuah karya akademik dan belum memadai baik itu dari segi isi, sistematika penelitian dan lain sebgainya, ini menjadi beberapa alasan beberapa institusi atau pihak akademik beberapa universitas belum berani membuat publikasi karya ilmiah secara terbuka.

5. Anggaran/ Dana ,Hambatan dana ini biasanya terjadi pada perpustakaan perguruan tinggi yang anggaran relatifnya terbatas jika di bandingkan unit akademik kampusnya, Padahal seperti yang kita ketahui untuk membangun dan mengembangkan repositori akses terbuka diperlukan dana yang cukup besar 42

6. Beberapa Database yang sudah memberikan Free Acces (OAIR) di perguruan tinggi seperti DOAJ,OARE,HINARI dan lain sebagainya ada yang tidak dapat di akses secara perseorangan atau individu, membuat perguruan tinggi musti melanggannya agar tetap bisa di akses oleh seluruh civitas akademik kampus yang membutuhkan, namun perguruan tinggi tersebutb haruslah melakukan pelangganan agar tetap bisa di akses, dan hal ini pun dapat dilakukan hanya saat kita berada didalam lokasi perguruan tinggi .

\footnotetext{
${ }^{42}$ Dwi Novita Ernaningsih, 'Kebijakan Akses Institusional Repository: Studi Kasus Di Perpustakaan Universitas Negeri Malang', 3 (2017), 25-37.
} 
7. Kemudian masalah berikutnya adalah mengapa Open Akses masih belum semua perguruan tinggi di indonesia melakukan nya adalah karena jumlah mahasiswa yang tidak sebanding dengan dosen yang ada didalam sebuah perguruan tinggi. Hal ini membuat waktu dosen untuk memperhatikan dan membimbing mahasiswanya untuk membuat karya ilmiah yang bagus dan berkualitas tidak ada , karena untuk melakukan hal ini membutuhkan waktu waktu dan ke fokusan yang tinggi .43

\section{Tren Saat Ini Dan Masalah Dalam Komunikasi Ilmiah}

\section{Pengertian Komunikasi Ilmiah}

Menurut Online Dictionari for Library Information Science (ODLIS) ,komunikasi ilmiah merupakan sarana yang digunakan oleh individu yang memiliki sebuah karya penelitian dengan cara menginformasikan. Mereka berkomunikasi dengan menulis monograf dan artikeljurnal untuk publikasi, yang tujuannya tentunya agar diterbitkan. Salah satu tujuan dari Sementara itu, American Library Association (ALA) mendifinisaikan komunikasi ilmiah sebagai suatu kegiatan dimana hasil-hasil karya ilmiah dari para peneliti yang sudah diciptakan di eavluasi kualitasnya sehingga dapat di sebarluaskan kepada masyarakat ilmiah tentunya dengan tujuan agar penelitian atau hasil karya ilmiah ini tetap bisa digunakan di masa depan.

Dengan demikian, dari beberapa pengertian yang sudah di paparkan di atas dapat kita tarik kesimpulan bahwa komunikasi ilmiah itu adalah proses penyampaian hasil karya ilmiah seorang peneliti yang dituangkan dalam bentuk tulisan yang dimuat didalam sebuah jurnal ilmiah. Dalam hal ini perpustakaan lah yang berperan sebagai lembaga yang menjadi pengolah karya ilmiah si peneliti tadi, memfasilitasi serta memberikan sarana

\footnotetext{
${ }^{43}$ Ernaningsih.
} 
komunikasi ilmiah bagi si pemilik karya ilmiah yang tujuannya tentunya agar hasil karya ilmiah yang masuk ke perpustakaan telah siap di konsumsi oleh masyarakat luas baik itu seperti para mahasiswa, dosen, ataupun para peneliti. ${ }^{44}$

Dengan demikian perpustakaan telah melaksanakan peranannya sesuai dengan UU NO. 43 Tahun 2007 pasal 24, dimana perpustakaan tidak hanya sebagai penerima hasil karya ilmiah para peneliti, dosen atau mahasiswa mentah-mentah tetapi juga berperan sebgai pengelola karya ilmiah tersebut agar lebih baik lagi sekaligus menjadi wadah dan sarana untuk hasil karya ilmiah barulah berlangsung komunikasi ilmiah yang semestinya.

\section{Komunikasi Ilmiah di Lingkungan Akademik dan Perpustakaan}

Secara sederhana Scholarly Communication atau komunikasi ilmiah gambarannya kurang lebih seperti dibawah ini

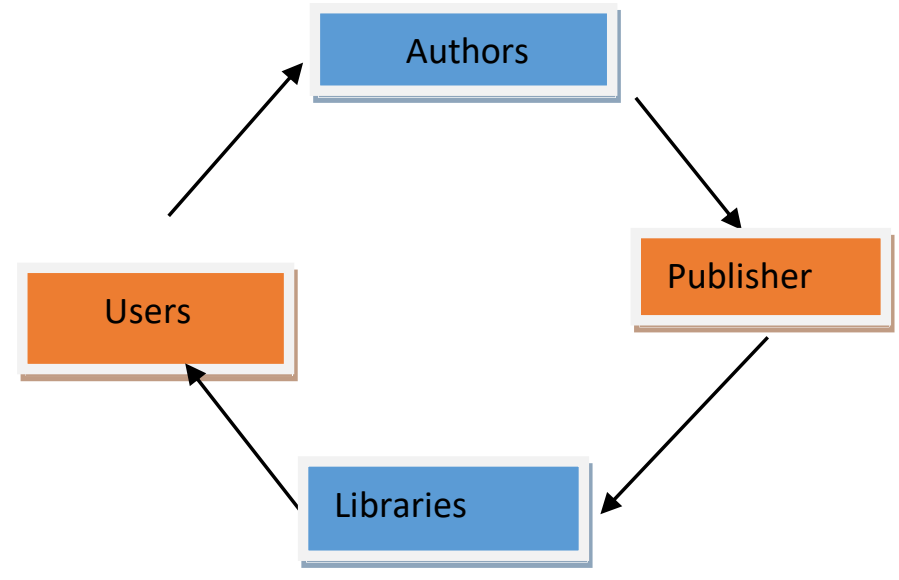

Seperti yang tertera pada gambar diatas Penulis, penerbit, perpustakaan dan pemustaka merupakan unsur-unsur yang sangat mempunyai peranan yang cukup penting agar komunikasi ilmiah tetap berlangsung . ke-empat unsur ini Masing-masing telah mempunyai serta memberikan kontribusi atau peranan

\footnotetext{
${ }^{44}$ Arif Cahyo Bachtiar, 'Membangun Media Komunikasi Ilmiah Di Perpustakaan Perguruan Tinggi'.
} 
cukup sehingga komunikasi ilmiah tetap berlangsung. Jika seandainya salah satu dari keempat unsur diatas mengalami hambatan atau masalah makan komunikasi ilmiah juga akan turut serta mengalami hambatan, itulah saking eratanya kaitan unsur-unsur yang ada diatas dan serta peranannya dalam komunikasi ilmiah. ${ }^{45}$

Keterikatan dari ke-4 unsur Tersebut tentunya berjalan sesuai dengan perannya masing-masing. Bahkan terkadang dalam pengaplikasiannya antar denganyang lainnya tidak saling "bersentuhan" sehingga unsur-unsur ini hanya berkomunikasimelalui pada saat proses terjadinnya komunikasi ilmiah itu sendiri. Unsur-unsur ini tanpa diatur telah menjalankan funsinnya masing-masing dengan baik dan alamiah. Seperti Perpustakaan seperti pada fungsinnya sudah sangat jelas perannya dalam scholarly communication yaitu Dengan mengorganisir atau By organizing, menyebarluaskan atau disseminating, dan menyediakan akses ke informasi atau providing access to information, pustakawan dan arsiparis bertindak sebagai penjaga pengetahuan bagi banyak siswa atau librarians andarchivists act as gatekeepers of knowledge forcountless students, peneliti atau researchers, dan profesor (Sugitomo, 2012). Dalam hal ini pustakawan disebut sebagai gatekeepers atau yang menjadi penjaga gawang dalam hal keilmuan pengetahuan .

Berikut proses terjadinnya Komunikasi ilmiah di dalam sebuah perpustakaan melalui hasil karya ilmiah berupa jurnal

\footnotetext{
${ }^{45} \mathrm{Irman}$ Siswadi, 'PENGUATAN PERAN PERPUSTAKAAN DALAM KOMUNIKASI ILMIAH ( SCHOLARLY COMMUNICATION ) DI LINGKUNGAN AKADEMIK', 12.1 (2004), 8-15.
} 


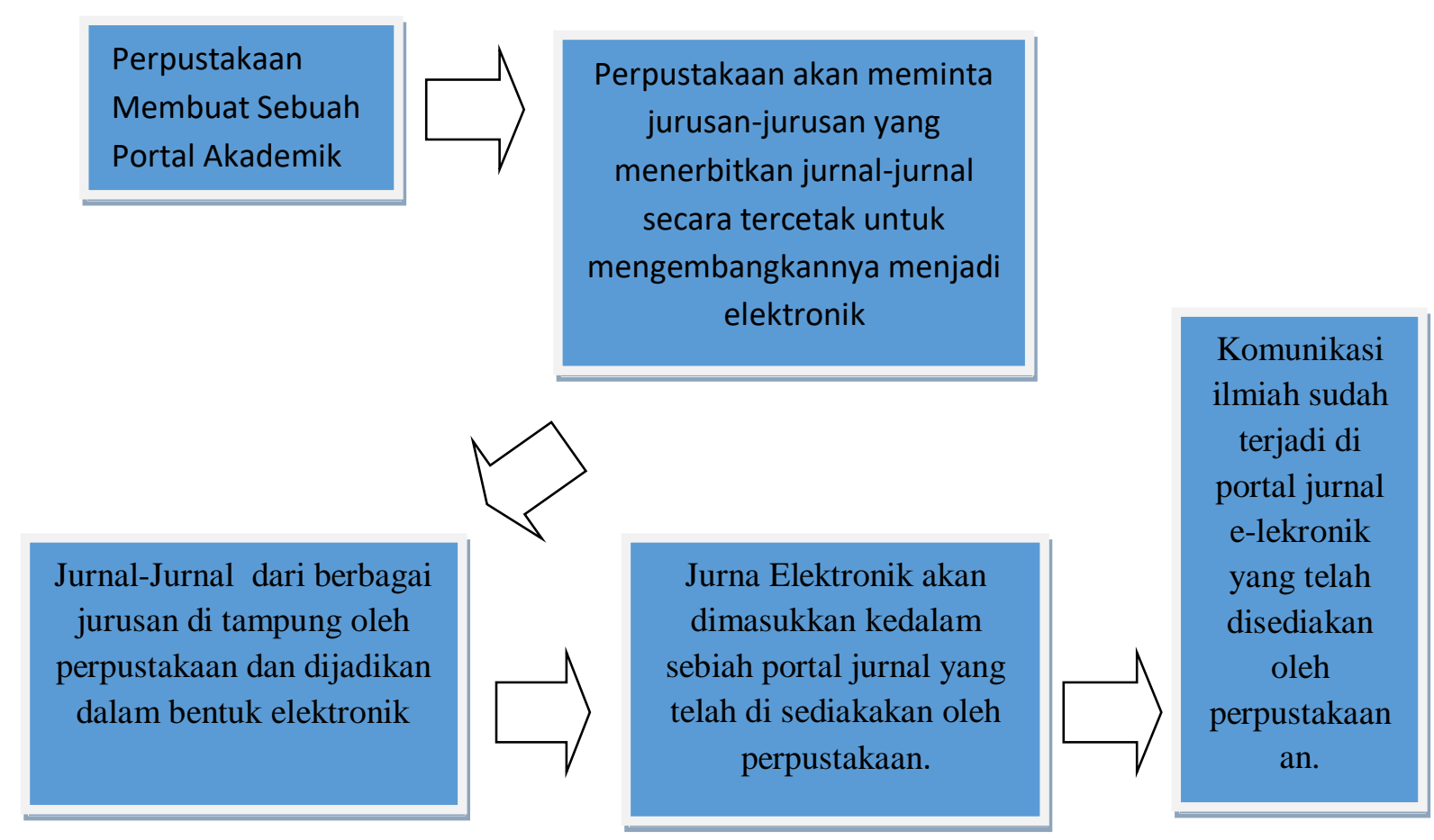

Seperti yang sudah tertera diatas bahwa perpustakaan telah menyediakan wadah atau sarana komunikasi ilmiah untuk segenap akademik kampusnya. Dengan memanfaatkan sistem pengelollaan jurnal e-lektronik seperti OJS dengan demikian perpustakaan telah membantu Para peneliti atau penulis karya ilmiah mempublikasikan hasil karya nya yang dimuat atau yang sudah di upload dalam portal jurnal eletronik tersebut.

\section{Strategi Untuk Mempertahankan dan Mendukung Proses Komunikasi Ilmiah}

Ada Beberapa strategi yang dapat kita lakukan jika kita berada di lingkungan Akademik agar tetap bisa mendukung tetap berjalannya proses komunikasi ilmiah yaitu sebagai berikut:

1. Tetap bersedia dan Tetap mempertahankan hak untuk menyebarkan dan melestarikan ilmupengetahuan maupunhasil karya ilmiah agar terus berkembang 
2. Mengembangkan sarana dan prasarana yang berguna untuk mempertahankan komunikasi ilmiah baik itu alat, kebijakan daninfrastruktur untuk membantu penyebaran ilmu pengetahuan dan karya-karya ilmiah

3. memberikan Apresiasi atau penghargaan kepada mereka yang tetap bersedia dan memfokuskan dirinya untuk mengembangkan Komunikasi ilmiah .

4. menfokuskan pada usaha-usaha penyebaran ilmu pengetahuan atau karya-karya yang bersifat ilmiah.Dan masih banyak lagi hal yang dapat dilakukan agar tetap bisa mempertahankan berjalannya komunikasi ilmiah di kalangan akademik.

Jika hal-hal seperti diatas telah dilakukan maka dapat dikatakan bahwa lingkungan akademik telah melakukan gerakan yang mencoba untuk memepertahankan proses komunikasi ilmiah itu sendiri. Komunikasi ilmiah itu sendiri dapat dikatakan berjalan lancar apabila seluruh karya ilmiah yang ada di lingkungan akademik dapat di digunakan atau di akses oleh seluruh masyarakat pembaca contoh kecilnya seperti jurnal yang merupakan salah satu terbitan satu jenis terbitan yang di ciptakan oleh dikeluarkan oleh para ilmuwan dari berbagai macam disiplin ilmu yang ada di lingkugan akademik atau perguruan tinggi yang biasanya berada dibawah naungan fakultas atau jurusan. Jika jurnal tersebut mempunyai kualitas yang bagus maka perguruan tinggi akan menyebarluaskannya agar di kases oleh orang-orang atau para peneliti yang membutuhkan karya tersebut. ${ }^{46}$

\section{Masalah atau Hambatan Yang Sering Muncul Dalam Komunikasi Ilmiah}

1. Keterbatasan pengetahuan akan teknologi .Komunikasi ilmiah di era teknologi ini telah menciptakan cara yang baru untuk mengkomunikasikan hasil karya ilmiah dan hasil penelitian

\footnotetext{
${ }^{46}$ Bachtiar.
} 
yang menuntut atau dengan kata lain memaksa para peneliti untuk mulai mengenal dan harus belajar menggunakan internet guna untuk mempublikasikan hasil karyanya sedangkan para peneliti dengankarya-karya nya yang berkualitas tinggi atau bagus banyak yang sudah tua dan sudah agak sulit dalam memahami teknologi padahal sebenarnya banyak sekali karya-karya atau hasil penelitiannya yang cukup bagus.

2. Faktor Fasilitas dan SDM (Pustakawan) di Perpustakaan. Perpustakaan sebagai wadah bagi hasil karya-karya ilmiah ataupun hasil penelitian dari masyarakat akademik haruslah mempunyai fasilitas yang memadai juga terutama yang tekait dengan proses Komunikasi ilmiah agar tercipta Scholarly comunication yang baik. Dan tentunya hal ini juga harus didukung oleh SDM atau pustakawan yang mampu mengolah karya-kaya atau hasil penelitian yang ada agar terciptaproses komunikasi ilmiah yang semestinya.

3. Kurangnya critical skill (keahlian yang kritis) . seperti yang kita ketahui bahwa para Pengajar dan peneliti menyalurkan dengan cara melakukan penelitian, se3dangkan mahasiswa dengan tugas akhirnya yang wajib menghasilkan skiripsi, disertasi dan tesis yang tentunya ini adalah sebuah karya atau penelitian yang ilmiah tulis kembali dan menyulapnya jadi dalam bentuk sebuah artikel kemudian dituangkan dalam jurnal-jurnal ilmiah yang ada maka hasil karya ini akan bisa di publikasikan, namun sayangnya tidak banyak mahasiswa yang melakukan ini , karena untuk memahami artikel ilmiah tersebut dibutuhkan keahlian yang kritis. ${ }^{47}$

4. Faktor kebijakan perpustakaan. Ada beberapa perpustakaan perguruan tinggi yang hanya menampung jurnal-jurnal ilmiah 
yang langsung diluncurkan untuk dikonsumsi tanpa melakukan pengolahan.

\section{KESIMPULAN}

Open Access (OA) atau yang biasa kita sebut sebagai akses terbuka saat ini dapat kita katakan sebagai salah satu cara yang paling alternatif dalam menyebar luaskan informas- informasi ilmiah yang ada kepada seluruh penjuru dunia tanpa dibatasi oleh yang namanya ruang,tempat dan waktu . Sedangkan komunikasi ilmiah itu sendiri adalah proses penyampaian hasil karya ilmiah seorang peneliti yang dituangkan dalam bentuk tulisan yang dimuat didalam sebuah jurnal ilmiah. Dalam hal ini perpustakaan lah yang berperan sebagai lembaga yang menjadi pengolah karya ilmiah si peneliti tadi, memfasilitasi serta memberikan sarana komunikasi ilmiah bagi si pemilik karya ilmiah yang tujuannya tentunya agar hasil karya ilmiah 


\section{DAFTAR PUSTAKA}

Arif Cahyo Bachtiar, 'Membangun Media Komunikasi Ilmiah Di Perpustakaan Perguruan Tinggi'.

Chusnul Chatimah Asmad, Taufiq Mathar, and A Khaidir Akbar, 'TREN PERKEMBANGAN OPEN ACCESS INSTITUTIONAL REPOSITORY PADA', 2018.

Dwi Novita Ernaningsih, 'Kebijakan Akses Institusional Repository: Studi Kasus Di Perpustakaan Universitas Negeri Malang', 3 (2017), 25-37.

Endang Fatmawati, 'Revolusi Budaya Digitalisasi Informasi: Dampaknya Bagi Pustakawan Dalam Mengelola Pengetahuan', 11.02 (2017), 1-16.

Irman Siswadi, 'PENGUATAN PERAN PERPUSTAKAAN DALAM KOMUNIKASI ILMIAH ( SCHOLARLY COMMUNICATION ) DI LINGKUNGAN AKADEMIK', 12.1 (2004), 8-15. 